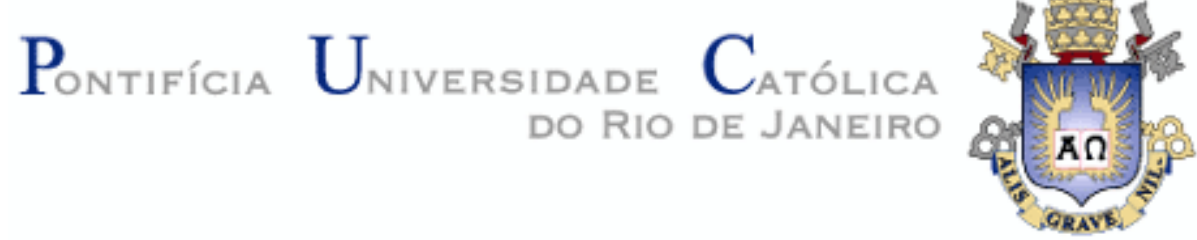

Bruno Duarte Azevedo

Análise e Proposta de Diretrizes para um Sistema Logístico de Recolha e Beneficiamento dos Resíduos Sólidos para Áreas de Favela em Sintonia com os Preceitos do GrSCM

Dissertação de Mestrado

Dissertação apresentada ao Programa de PósGraduação em Engenharia de Produção do Departamento de Engenharia Industrial da PUC-Rio como requisito parcial para obtenção do título de Mestre em Engenharia de Produção.

Orientador: Prof. Luiz Felipe Roris Rodriguez Scavarda do Carmo 
Bruno Duarte Azevedo

\section{Análise e Proposta de Diretrizes para um Sistema Logístico de Recolha e Beneficiamento dos Resíduos Sólidos para Áreas de Favela em Sintonia com os Preceitos do GrSCM}

Dissertação apresentada ao Programa de PósGraduação em Engenharia de Produção do Departamento de Engenharia Industrial da PUC-Rio como requisito parcial para obtenção do título de Mestre em Engenharia de Produção. Aprovada pela Comissão Examinadora abaixo assinada.

Prof. Luiz Felipe Roris Rodriguez Scavarda do Carmo

Orientador

Departamento de Engenharia Industrial - PUC-Rio

Prof. Osvaldo Luiz Gonçalves Quelhas Departamento de Engenharia de Produção - UFF

Prof. Madiagne Diallo Departamento de Engenharia Industrial - PUC-Rio

Prof. José Eugenio Leal Coordenador Setorial do Centro

Técnico Científico - PUC-Rio 
Todos os direitos reservados. É proibida a reprodução total ou parcial do trabalho sem autorização da universidade, do autor e do orientador.

\section{Bruno Duarte Azevedo}

Graduou-se em Engenharia Sanitária e Ambiental pela Universidade Federal de Santa Catarina. Foi bolsista por 3 anos no Projeto "Ações Ambientais na Comunidade da Serrinha e a Cidadania" e estagiou na empresa Tecnipar Engenharia Ambiental. Depois de graduado trabalhou como consultor na área de gerenciamento sólido na comunidade da Rocinha e ingressou no Programa de Pós-graduação em Engenharia Industrial da PUC-Rio para obtenção do título de Mestre.

\section{Ficha Catalográfica}

Azevedo, Bruno Duarte

Análise e proposta de diretrizes para um sistema logístico de recolha e beneficiamento dos resíduos sólidos para áreas de favela em sintonia com os preceitos do GrSCM / Bruno Duarte Azevedo ; orientador: Luiz Felipe Roris Rodriguez Scavarda do Carmo. - 2010. 133 f. : il. (color.); $30 \mathrm{~cm}$

Dissertação (Mestrado em Engenharia Industrial)Pontifícia Universidade Católica do Rio de Janeiro, Rio de Janeiro, 2010.

Inclui bibliografia

1. Engenharia Industrial - Teses. 2. Gestão da cadeia de suprimentos. 3. Logística verde.4. Favela. 5. Resíduos sólidos.6. Reciclagem. 7. Sustentabilidade. 8. Engenharia da sustentabilidade. 9. Responsabilidade social. I. Carmo, Luiz Felipe Roris Rodriguez Scavarda do. II. Pontifícia Universidade Católica do Rio de Janeiro. Departamento de Engenharia Industrial. III. Título. 
À minha avó, Dona Zilda, e à minha tia Sônia, in memoriam 


\section{Agradecimentos}

À toda minha família, em particular aos meus incomparáveis pais, Roberto Azevedo e Izabel Azevedo, pelo grande incentivo, carinho, compreensão, confiança e ensinamentos.

Ao meu professor e orientador Luiz Felipe Scavarda, por acreditar numa proposta completamente nova. Obrigado pela confiança, dedicação e conhecimentos transmitidos.

Ao arquiteto Toledo, pela sua extraordinária competência, carinho, visão e enorme determinação para democratizar a arquitetura.

Ao gerente local da COMLURB, Luiz Gonzaga.

Ao PC e ao Marat, incansáveis na busca por uma Rocinha melhor.

Ao grupo dos Garis Comunitários, sempre dispostos a me acompanhar em longas caminhadas, bombardeados por perguntas infinitas.

Aos meus irmãos Eduardo e Fernando Azevedo, aos meus amigos de turma, e a todos aqueles que de alguma forma contribuíram para a realização deste trabalho.

Aos professores e funcionários do DEI da PUC-Rio, pelo apoio e infra-estrutura.

Ao CNPq, pelo apoio concedido durante o curso. 


\section{Resumo}

Azevedo, Bruno Duarte; Scavarda, Luiz Felipe. Análise e Proposta de Diretrizes Para um Sistema Logístico de Recolha e Beneficiamento dos Resíduos Sólidos Para Áreas de Favela em Sintonia com os Preceitos do GrSCM. Rio de Janeiro, 2010. 133 p. Dissertação de Mestrado Departamento de Engenharia Industrial, Pontifícia Universidade Católica do Rio de Janeiro.

O gerenciamento de resíduos sólidos tornou-se um tema de preocupação para administradores públicos de todo o mundo. O aumento no nível de consumo, somado ao uso indiscriminado de materiais descartáveis, despertou na opinião pública movimentos que cobram das empresas uma nova postura referente à preservação dos recursos naturais. O Green Supply Chain Management GrSCM, surge como uma nova forma de gerenciamento da cadeia de suprimentos que leva em conta todo o ciclo de vida do produto, desde a extração de suas matérias-primas, até sua disposição final. Uma vez que a aplicação deste conceito ainda é incipiente, o presente trabalho inicialmente apresenta uma abordagem das principais definições descritas na literatura para os termos ligados ao GrSCM. Em seguida, a partir de um diagnóstico que referencia a situação dos resíduos sólidos na comunidade da Rocinha, uma favela no Município do Rio de Janeiro, propõe diretrizes gerais para um sistema logístico de recolha e beneficiamento destes resíduos (com destaque aos recicláveis) para áreas de favela em geral, buscando medidas práticas de aplicação do conceito de GrSCM em locais de ocupação irregular e pobreza acentuada. As diretrizes foram traçadas sob três perspectivas: a dos empresários geradores dos produtos; a dos moradores e organizações locais e a dos órgãos públicos e instituições responsáveis pela coleta e limpeza da região. Como conclusão, defende-se que para o bom funcionamento de um sistema de gerenciamento de resíduos a partir da aplicação do GrSCM em realidades tão complexas, governo e empresas privadas devem ser parceiros e atuar de forma coordenada. Cabe ainda aos moradores e organizações locais, o dever de cobrar, adotar, fiscalizar e promover ações que visem o bem estar do local onde vivem.

\section{Palavras-chave}

Gestão da Cadeia de Suprimentos; Green Supply Chain Management; Logística Verde; Favela; Resíduos Sólidos; Reciclagem, Sustentabilidade; Engenharia da Sustentabilidade; Responsabilidade Social. 


\begin{abstract}
Azevedo, Bruno Duarte; Scavarda, Luiz Felipe. Analysis Scope and Guidelines Proposal of a Collection and Treatment Logistic System for Solid Waste in Slums Areas in Harmony with GrSCM Precepts. Rio de Janeiro, 2010. 133 p. M. Sc. Dissertation - Departamento de Engenharia Industrial, Pontifícia Universidade Católica do Rio de Janeiro.
\end{abstract}

Municipal solid waste management (MSCM) has become a topic of concern for public administrators all over the world. The increase in the level of consumption added to the indiscriminate use of disposables, gave rise to public opinion movements that require new approaches from companies in order to preserve the natural resources. The Green Supply Chain Management (GrSCM) emerges as a new way of managing the supply chain that takes into account the whole life cycle of the product, from the extraction of raw materials to its correct final disposal. Since the application of this concept is still new, this dissertation initially defines the main terms related to the GrSCM described in the literature. Following, based on MSW data obtained on the Rocinha community, in the Rio de Janeiro municipality, general guidelines of a logistic system for the collection and processing of waste (with emphasis on recycling) in slum areas aiming to achieve practical measurements for the application of the GrSCM concept are proposed. These guidelines were drawn from three perspectives: that of the entrepreneurs that generate the goods; that of the residents and local organizations; and that of the public agencies and institutions responsible for collecting and cleaning the area. In conclusion, it is argued that for the proper functioning of a MSW management system in complex neighborhoods based on the application of GrSCM, government and entrepreneurs must be partners and act in a coordinated manner. Besides, the residents and local organizations must adopt, promote and monitor actions that aim the welfare of the local where they live.

\title{
Keywords
}

Supply Chain Management; Green Supply Chain Management; Green Logistics; Slum; Solid Waste; Recycling; Sustainability; Sustainability Engineering; Social Responsibility. 


\section{Sumário}

1- INTRODUÇÃO

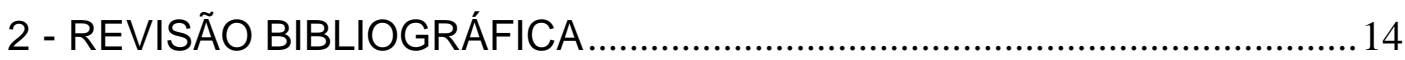

2.1 Introdução à Logística e ao Supply Chain Management ...................... 14

2.2 Logística Reversa e a Logística Verde ........................................... 17

2.3 Introdução ao Green Supply Chain Management - GrSCM ................ 24

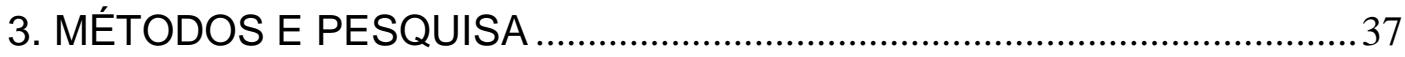

4. DIAGNÓSTICO

4.1. Caracterização da Comunidade ................................................... 40

4.2 O Manejo dos Resíduos Sólidos na Rocinha ..................................... 44

4.3 análise parcial da Distribuição do Lixo da Rocinha ............................ 52

5. DIRETRIZES PARA O PROCESSO DE GERENCIAMENTO DE

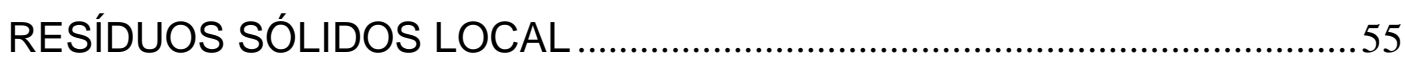

5.1 Diretrizes Aplicadas ao Grupo dos Empresários Geradores; .............. 56

5.2 Diretrizes Aplicadas ao Grupo dos Moradores e Org. Locais:............. 59

5.3 Diretrizes Aplicadas ao Grupo dos Órgãos Públicos e Instituições

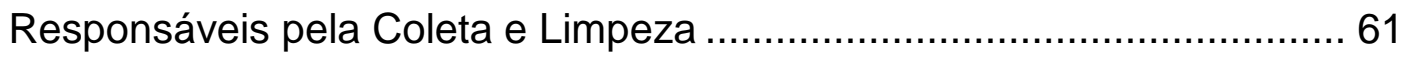

5.4 Estratégias de Sensibilização e de Comunicação Visual para com o

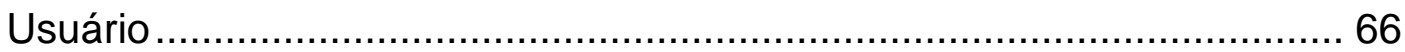

5.5. Estratégias para ampliação da Coleta Seletiva ................................. 67

5.6. Considerações Finais ................................................................. 72

6. CONCLUSÕES

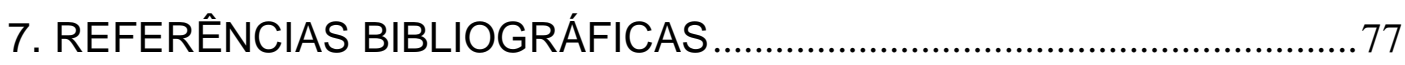

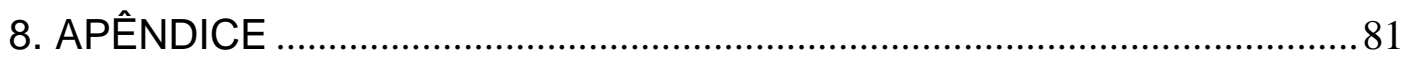

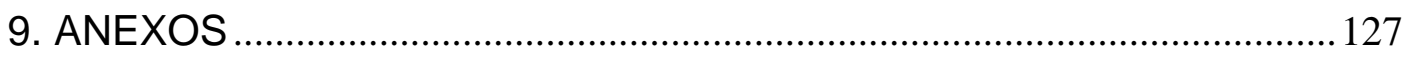




\section{Lista de Figuras}

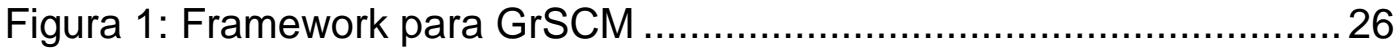

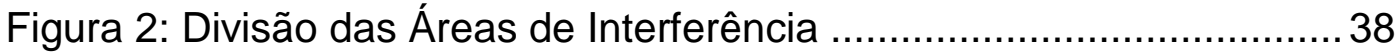

Figura 3: O que sobrou da antiga delimitação do Eco-Limite..................... 42

Figura 4: Situação - Mutirões............................................................ 43

Figura 5: Situação Geral - Coleta Rocinha .......................................... 44

Figura 6: Mapa institucional das organizações atuantes nos serviços de

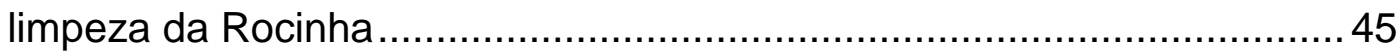

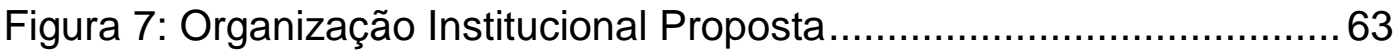




\section{Lista de Tabelas}

Tabela 1: Classificação de publicações e atividades ligadas à logística ... 23

Tabela 2: Distribuição do lixo da Rocinha ............................................ 52 